\title{
ERAZMOVA KRŠĆANSKA FILOZOFIJA ODGOJA U SVOJSTVU UTEMELJENOG ODGOJA ZA VLADARA
}

\author{
Petar Jakopec
}

Druga gimnazija Varaždin i

UDK: 1:159.942.7]:Erasmus,D.

Elektrostrojarska škola Varaždin

$(179.9+27-423.79) 342.511$

petar.jakopec@gmail.com

https://doi.org/10.34075/cs.56.2.8
Pregledni znanstveni rad
Rad zaprimljen 8/2020.

\section{Sažetak}

U članku autor problematizira i uturđuje krajnji smisao Erazmova Kršćanskog vladara koji je Erazmo priredio kao priručnik o kršćanskom odgoju za tada mladog kralja Karla V. Habsburškog. Članak je podijeljen na tri cjeline, odnosno na tri poglavlja te sveukupno na sedam manjih potpoglavlja; njih pet manjih odnose se na drugu cjelinu, a preostala dva na treću cjelinu. Ukratko, u prvoj cjelini govori se o konačnom idealu Erazmova kršćanskog vladara, u drugoj cjelini o Erazmovoj kršćanskoj filozofiji odgoja te naposljetku, u trećoj cjelini, o habitusu kršćanskog vladara. Temeljitom razradom Erazmova Kršćanskog vladara, na osnovi konkretnih i provjerenih te argumentiranih razloga, autor u članku utvrđuje kako je Erazmovo promišljanje odgoja u svojstvu kršćanske filozofije odgoja, definitivno usmjereno na odgoj vladara $u$ kršćanskoj etici ljubavi $i$ vrline, na vladanje za opće dobro političke zajednice.

Ključne riječi: filozofija odgoja, Erazmo Roterdamski, Kršćanski vladar, vladar, vrlina.

\section{UvOD}

Erazmovo je djelo Kršćanski vladar ponajprije pripremljeno za odgajanika koji će postati kralj ili vladar neke političke zajednice, a tek potom kao djelo ili odgojni priručnik koji može poslužiti svakom pojedincu u zauzimanju za odgoj u kršćanskim vrijednostima. Upravo iz tog razloga Erazmo svojega Kršćanskog vladara započinje problematiziranjem o važnosti posjedovanja posebnih kršćanskih karakternih osobina i vrijednosti. Prije svega određuje kako je sklonost prema mudrosti, pravedno djelovanje i benevolentnost prema drugim ljudima, a napose prema pripadnicima političke zajed- 
nice nad kojom ima ingerenciju vladanja, presudno za moralni habitus dobrog vladara. Ključna je nakana autora u ovome članku izvornom kreativnom interpretacijom istražiti i ustanoviti Erazmovu kršćansku filozofiju odgoja te istaknuti njegova promišljanja o odgoju kao prototip zrela kršćanskog odgoja. Iako se u Erazmovo vrijeme filozofija odgoja nije još nazirala, a filozofija se tek započela podrobnije razvijati i dijeliti na manje filozofske discipline, Erazmo je Kršćanskim vladarom uspio pripremiti plodno tlo za daljnji napredak kršćanske filozofije odgoja. Temeljna je teza kako mladog odgajanika koji će postati vladar političke zajednice, valja odgajati i poučavati na vrijeme u svim kršćanskim vrijednostima i vrlinama, kako bi odgajanik postao dobar kršćanski vladar, koji će benevolentno vladati za opće dobro političke zajednice.

\section{IDEAL KRŠĆANSKOG VLADARA}

Erazmo Roterdamski (1466. - 1536.) raspravu Kršćanski vladar ${ }^{1}$ započinje polemikom o bitnim značajkama kršćanskog vladara. Dakle temeljni "preduvjet za postati dobar vladar, kao i dobar građanin, jest odgoj i obrazovanje koje počinje $u$ ranoj dobi “. ${ }^{2} \mathrm{U}$ tom je kontekstu potrebno, ističe Erazmo, da budući vladar bude staložena duha, da na vrijeme započinje odgoj, zatim da bude komunikativan, nije dobro da bude apatičan, već je potrebno da ima iza sebe dovoljno životnog iskustva te da naposljetku postane zrela osoba. ${ }^{3}$ Stoga Erazmo, kao i ostali renesansni mislioci o idealu čovjeka kao univerzalnog bića (homo universalis), raspravlja koje su ključne moralne osobine potrebne da bi vladar mogao pravedno i kršćanski vladati. Prema tome "vlast [je op. a.] najbolje dati onome koji državničkim sposobnostima nadmašuje ostale: a to bi naime bile mudrost, pravednost, umjerenost, providnost i briga za opće dobro". ${ }^{4}$ Osnovna je Erazmova pretpostavka dobrog vladara poučenost u temeljnim kršćanskim, štoviše stožernim skolastičkim vrlinama.

1 Više o povezanosti Erazmova djela Kršćanski vladar (Institutio principis christiani), koje je Erazmo objavio 1516. godine, kada je službovao na dvoru Karla V. Habsburškog, u funkciji kraljevskog savjetnika, vidi u: Johan Huizinga, Erasmus and the Age of Reformation, Princeton University Press, Princeton, 1984., 91-93.

2 Miro Dundić; Bruno Ćurko, Povezanost teorije kritičkog mišljenja s promišljanjem o odgoju Erazma Roterdamskog, Filozofska istraživanja 39 (2019.) 3, 687696, 688.

3 Usp. Erazmo Roterdamski, Kršćanski vladar, Nakladni zavod Globus, Zagreb, $2011 ., 87$.

$4 \quad$ Isto, 87. 
Temeljna politička preokupacija ozbiljnog kršćanskog vladara jest briga za opće dobro svih pripadnika političke zajednice, a nikako težnja za što više materijalnog bogatstva. Upravo suprotno od materijalnog bogatstva, Erazmo se zalaže za duhom ispunjena i bogata vladara. Naime, "jedino što vladar u vladanju treba uzeti u obzir isto je ovo što treba i narod kod biranja vladara: to je opće dobro, dok osobni osjećaji moraju biti posve po strani. Jer kao što nije pametno mijenjati jednom izabrana vladara, tako treba kod biranja biti što oprezniji da nas nepromišljenost jednog trenutka ne bi mučila jako dugo vremena". ${ }^{5}$

Uzajamna sveza vladara s pripadnicima političke zajednice rezultira pravednim i uravnoteženim političkim poretkom, u kojemu opće dobro postaje primarni cilj političke zajednice. Iako Erazmo ističe kako je dobar odgoj neophodan samo u onim političkim zajednicama koje su monarhističkog uređenja, budući da u slobodnim i demokratskim političkim zajednicama biranje vladara jest res publi$c a$, ipak se može istaknuti kako je i u jednom i u drugom političkom uređenju potrebno imati dobro odgojene i vrle vladare. U tom smislu ističe Erazmo kako "domovina sve duguje dobrom vladaru. Ali njega samog dugujemo onome tko ga je mudrim savjetima takvim i napravio. A nema boljeg i prikladnijeg vremena za formiranje i popravljanje vladarova karaktera nego onda kada još nije ni svjestan da je vladar. A to treba tako marljivo raditi da ga se ne samo obrani od loših odluka, već i uvede u neka dobra učenja ${ }^{6}{ }^{6}$ Paternalistički pristup u odgoju mladog vladara svakako je odlika Erazmove metode odgajanja koja na prvo mjesto postavlja odgoj u vrlini, a zatim brigu za opće dobro, koja je prema Erazmu oličenje patriotizma. Štoviše, i samom vladaru kao odgajatelju valja "odgajati djecu da uvijek pamti kako su ona rođena i odgajana za domovinu, a ne za njegove vlastite interese «. ${ }^{7}$ Ako se odgajanika priprema za vladarsku dužnost, odgajatelj valja odgoju pristupiti oprezno i predano, kako bi odgajanik samostalno kada postane vladar mogao slobodno razlučiti što je dobro, a što nije kršćansko, to jest što ne služi općem dobru političke zajednice.

\section{ERAZMOV KRŠĆANSKI FILOZOFIJSKI ODGOJ}

Ispravan kršćanski odgoj od presudne je važnosti za vladarovo dobro vladanje i razumijevanje potreba političke zajednice. Stoga Erazmo ističe da "tko god preuzima zadaću odgoja vladara neka

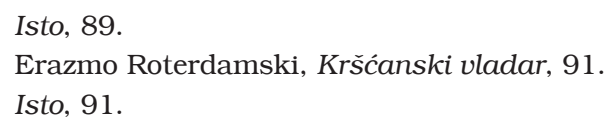


stalno misli na to da ne obavlja neki banalan posao, već da je od svih poslova ovaj daleko najveći, ali i daleko najopasniji«. ${ }^{8}$ Odgoj za vladara ne smije biti usmjeren na koristoljublje, već treba težiti dobrom kršćanskom odgoju, to jest prema razumijevanju i empatiji za opće dobro.

Ključno je pri odgajanju budućeg vladara imati budno pedagoško oko, te na vrijeme reagirati ako se primijeti da odgajanik može zahiriti u razvoju. Prema tome "učitelj ne treba odustajati i biti obeshrabren ako je vladar slučajno neobuzdanije i teže naravi. Ne postoji, naime, tako divlja i luda zvijer koja se ne može ukrotiti brigom i radom krotitelja; pa može li netko vjerovati da postoji tako beznadno divlja ljudska duša da se ne da smekšati mudrim odgojem? ". ${ }^{9}$ Vrlina je za Erazma osobina i značaj osobnosti vladara, a ustrajan te nepokolebljiv odgojni rad metoda kojom se postiže upravo vrli vladar. Naime, tvrdi Erazmo, "pažnje je vrijedno samo ono što proizlazi iz nečeg časnog. Dostojanstvo, veličinu i visočanstvo vladara treba graditi i čuvati mudrošću, poštenjem i pravednim postupcima, a ne igrom sreće ". ${ }^{10}$ Ukratko, vladar bi trebao, kao i u Platonovoj Državi, postati filozof, to jest pokazivati sklonosti prema mudrosti, a konačni je cilj posjedovati unutarnje kršćanske moralne vrijednosti. U tom kontekstu Grubiša ističe kako "obrazovati vladara znači stvoriti političara koji će istovremeno biti i filozof, po platonskom idealu, ali u smislu poimanja filozofije kao moralne doktrine kršćanstva: religija ima odlučujuću ulogu utoliko što ona može promijeniti čovjeka iznutra, a ne samo na površini, kao što to zagovaraju drugi pisci koji se bave politikom". ${ }^{11}$

\subsection{Erazmovo shvaćanje uloge vladara}

Erazmovo poimanje vladara podrazumijeva stapanje vladarske dužnosti i njegove osobnosti u etici ljubavi prema svim pripadnicima političke zajednice. Stoga je Erazmovo razumijevanje vladara kao filozofa posebno, jer "filozof nije onaj tko se razumije u dijalektiku i fiziku, već onaj tko prezire lažne prikaze realnosti i čista srca razmatra i slijedi pravo dobro. Biti filozof i biti kršćanin u stvari je jedno te isto, iako upotrebljavamo različite izraze". ${ }^{12}$ Vladar treba biti uzoran u svom držanju, oblikovati kršćansko promišljanje i usvo-

Isto, 95.

Erazmo Roterdamski, Kršćanski vladar, 99.

$10 \quad$ Isto, 105.

11 Damir Grubiša, Četiri orijentacije u političkoj misli europske renesanse, Politička misao 47 (2010.) 2, 7-36, 29.

12 Erazmo Roterdamski, Kršćanski vladar, 107. 
jiti kršćanske vrline, kako ne bi izazvao podvojena mišljenja glede svog vladanja. U tom smislu Erazmo neizravno podsjeća odgajanika za vladara: "Kad god se sjetiš da si vladar, odmah se prisjeti da si i kršćanski vladar, kako bi shvatio da moraš biti toliko daleko od slavnih poganskih vladara koliko i kršćanin od poganina. I zaista nemoj misliti da je kršćanska vjera bezbrižna i ugodna - osim ako bezvrijednim ne smatraš sakrament kojeg si između ostalog primio kod krštenja te se i jednom okreneš onome što se Sotoni dopada, a Kristu je mrsko."13 Dakle, odlika je vrsnog vladara jasno razlikovanje čestitog, odnosno moralnog djelovanja od beskrupuloznog i nemoralnog djelovanja.

Vladar koji brine za opće dobro, prema Erazmu, mari za summum bonum, nije opterećen svojim posebnim interesima, već interesima od opće važnosti i općeg dobra. Upravo je to temeljna odlika kršćanskog vladara. Naime Erazmo detaljno opisuje na koji način valja mladog odgajanika pripremiti za dosljednog kršćanskog vladara. Za njega on prije svega treba biti socijalno brižan vladar, koji je prihvatio Kristovo učenje. Stoga je Erazmov vladar neiskvaren, bori se protiv svakog oblika nepravde i teži mudrosti, a na koncu i istini. S druge strane, u konkretnom vladarovu djelovanju, "po Erazmu, vladati ne znači podčinjavati podanike ciljevima onoga koji vlada, već voditi, dobro upravljati, štititi i pružati sigurnost narodu stvaranjem širokog suglasja o ciljevima dobre uprave«. ${ }^{14}$ Tek prosvijećeni vladar koji je moralan i čestit može biti potpun vladar, koji doista u svakom pojedincu vidi dobro, a napose time što se dobrim vrlinama predstavlja kao uzor čitavoj političkoj zajednici.

\subsection{Postojanost vladarovih kršćanskih vrlina}

Mudrost je osnovna značajka dobra vladara pa "stoga, vladarov um mora biti podučavan s pomoću pravila i načela, tako da mudrost stekne uz pomoć teorije, a ne prakse. A iskustvo, kojeg zbog mladosti nema, nadomjestit će savjetima starijih". ${ }^{15}$ Prema Erazmu nije potrebno empirijsko iskušenje životnih prilika ili neprilika, naprotiv, potrebno je znati komunicirati, saslušati i savjetovati druge. Stoga nije nužno da mladi odgajanik za vladara bude starac, već je mnogo prječe da odgajanik naprosto ima sklonost prema mudrosti i ne teži hedonističkom stilu iskušavanja svih životnih blagodati. Nadalje, Erazmova je odgojna filozofija posve teocentrična, usmjerena na

13 Isto, 111.

14 D. Grubiša, Četiri orijentacije u političkoj misli europske renesanse, 29-30.

15 Erazmo Roterdamski, Kršćanski vladar, 117. 
Boga i njegovu svemoć te providnost. U tom smislu Erazmo oprezno upozorava odgajanika koji se priprema za vladara: "a ti, koji si i kršćanin i vladar, kad čuješ ili pročitaš da si slika Božja i njegov namjesnik, pazi da se zbog toga ne uzoholiš. Upravo neka te ta činjenica potakne da budeš nalik svom prelijepom uzoru. To postići, vrlo je teško. I vrlo sramotno, pak, ne postići to. ${ }^{16} \mathrm{U}$ Kršćanskom vladaru se naveliko može iščitati prožetost Erazmove odgojne filozofije kršćanskom etikom ljubavi, a napose isticanje teoloških krjeposti, vjere, ljubavi i nade. Iako ne posve izrijekom, Erazmo je itekako svjestan važnosti posjedovanja teoloških krijeposti, jer da bi vladar bio mudar i pravedan, najprije treba vjerovati $u$ postojanje Transcendencije, to jest u Boga. ${ }^{17}$

Iz preostalih teoloških krjeposti proizlazi dobro djelovanje koje ponajprije teži prema općem dobru za sve pripadnike političke zajednice. Śtoviše, Erazmo upozorava odgajanika kako »kršćanska teologija pridaje Bogu tri osobine: najveću moć, najveću mudrost i najveću dobrotu. Ovim trojstvom trebaš svim silama ovladati». ${ }^{18}$ Odgajanik koji se priprema za vladara, treba ostati ponizan, ne težiti prema oholosti, nego prema konačnoj spoznaji dobra i zla kako bi mogao ispravno djelovati. Da bi vladar bio dobar, "treba prema svojim građanima imati isti stav kao i dobar otac obitelji prema svojim ukućanima. A što li je drugo kraljevstvo nego jedna velika obitelj? Što je kralj, ako ne otac mnogim ljudima? Pravilno je, naime, rekao Aristotel da vladar nadvisuje ostale, ali ipak je pripadnik istoga roda i kao slobodan čovjek vlada nad slobodnim ljudima, a ne životinjama". ${ }^{19}$ Prije svega, čestiti će vladar vladati slobodno, pravedno, a nadasve mudro prema pripadnicima političke zajednice, nad kojom ima ingerenciju, jer u suprotnom je izgledna tiranijska metoda vladavine, što prema Erazmu nikako nije poželjno ni dobro. Stoga on podsjeća kako je "ono kraljevstvo kojim se upravlja plemenito i dobrohotno ne samo mirnije i ugodnije, nego i dugotrajnije i stabilnije. A to lako možeš vidjeti iz anala starijih pisaca. Nijedna tiranija nije bila tako čvrsta da se mogla dulje održati. A kad god se državno uređenje srozalo na tiraniju, uvijek se stropoštalo u propast. Onaj koga se svi plaše i sam se mora mnogih plašiti. A ni ne može biti siguran onaj koga najveći broj ljudi želi vidjeti mrtvog“. ${ }^{20}$

16 Isto, 121.

17 Više o Erazmovu poimanju vjere u Boga vidi u: Roland H. Bainton, Erasmus of Christendom, Scribner, New York, 1969., 37-38.

18 Erazmo Roterdamski, Kršćanski vladar, 121.

19 Isto, 143.

20 Isto, 149. 
Nerijetko i nedvosmisleno Erazmo tvrdi kako je najveća opasnost za političku zajednicu tiranijska vlast. Tiranija na sve načine ugrožava i potkopava stabilnost same političke zajednice i time sije buduće razdore, što na koncu može dovesti i do raspada utemeljene političke zajednice. Stoga se u svom Kršćanskom vladaru svim silama zalaže i jasno zagovara podučenost vladara u kršćanskim vrijednostima etike ljubavi, da bi konačno budući vladar svoje političko djelovanje mogao usmjeriti na opće dobro, odnosno summum bonum same političke zajednice. Prema Popkinu "za Erazma, što je neophodno jest jednostavno kršćanska pobožnost, i kršćanski duh".21

\subsection{Vladanje političkom zajednicom}

Koristeći se prenesenim značenjem, a kako bi preglednije i jasnije prikazao što je država kao politička zajednica i na čemu se temelji, Erazmo se služi metaforom tijela. Naime, "budući da je država kao neko tijelo sastavljeno od različitih udova, a među kojima se nalazi i sam vladar (iako izvrsniji od ostalih), nužno je služiti se takvim načinom vladanja da svima bude dobro, a ne da većina udova oslabi, dok jedan ili dva proizađu krepki i ugojeni. Jer veseli li se vladar i hrani zlima počinjenim nad državom, niti je on dio te države, niti je vladar, već razbojnik ". ${ }^{22}$ Upravo se iz tog razloga Erazmo trudi argumentirati potrebu odgajanja; on promišlja i nastoji pronaći najbolju odgojnu metodu te odgojnu filozofiju. Dobar odgoj je naprosto potreban, a napose kršćanski odgoj koji je prije svega usmjeren na zajednicu i na drugog čovjeka. Stoga je Erazmova odgojna filozofija najprije usmjerena na pitanje zašto odgajati, odnosno zašto je potreban dobar kršćanski odgoj. Ukratko, dobar je odgoj potreban da bi vladar kao upravitelj mogao postati istaknuti uzor kršćanskih vrlina za sve pripadnike političke zajednice nad kojima ima ovlasti, i na taj način potaknuti preostale pojedince da teže socijalnim kršćanskim vrijednostima. Stoga Erazmo ističe "ne možeš obavljati kraljevsku dužnost ako te ne vodi razum, tj. ne slijediš li u svemu savjet i prosudbu, a ne duševnu strast. I ne možeš vladati nad ostalima prije nego se sam ne pokoriš onome što je pošteno «. ${ }^{23}$ Vladati sobom obilježava slobodu od strasti te sebičnih poriva, i prema tome predstavlja predano služenje drugima.

Naizgled veoma oštar i isključiv u određivanju tko smije, a tko ne smije vladati, Erazmo ipak utvrđuje kako svaki vladar kao upra-

21 Richard H. Popkin, The History of Scepticism from Erasmus to Descartes, Van Gorcum \& Comp., Assen, 1960., 5.

22 Erazmo Roterdamski, Kršćanski vladar, 163.

23 Isto, 179. 
vitelj političke zajednice treba najprije znati vladati sobom, dakle slobodan biti od svojih strasti. Budući da "vladar, ako je dobar vladar, on je kao neka slika Boga. Koliko pak od ovog primjera odudaraju oni koji tako vode državu, da svako zlo koje se u državi rađa proizlazi iz njihovih grijeha? «. ${ }^{24} \mathrm{Na}$ toj misaonoj niti vladar političke zajednice bi trebao postati kritičan prema sebi, kako bi doista, prema Erazmu, mogao biti sličan Bogu koji je pun dobrote i ljubavi.

\subsection{Vrijednost pravilnog odgoja}

Konačni cilj kojemu vladar treba stremiti jest predanost Božjoj volji. Stoga je potrebno da sam vladar razumijeva vlastitu egzistenciju u svjetlu kršćanske vjere. Dapače, treba tako "odgajati vladara koji će vladati plemenitim ljudima slobodne volje. Neka nauči voljeti vrlinu, zazirati od sramote, stidjeti se nečasnih postupaka, a ne da ih izbjegava prisiljen strahom. Poboljšano ponašanje i zauzdani hirovi pružaju nadu u dobra vladara, ali osobita se nada polaže $u$ ispravne savjete«. ${ }^{25}$ Ključni razlog zašto pružiti dobar odgoj odgajaniku, budućem vladaru, jest da takav odgajanik postane oličenje kršćanskih vrlina i da mari za napredak te sveopće dobro političke zajednice. Međutim, kako bi odgajanik stasao pa kao vladar vladao pravedno i mudro, što je prema Erazmu osnovno obilježje kršćanskog vladara, potrebno je da ga kršćanskim vrijednostima poduči besprijekoran odgojitelj. Stoga "prva i osobita briga odgojitelja mora - kao što je već rečeno - biti kako u potpunosti iz vladarova uma odstraniti izopačena shvaćanja koja su tamo možda usađena te mu prenijeti spasonosne i kršćanskog vladara dostojne misli. ${ }^{26}$ Erazmova kršćanska filozofija odgoja upućuje na čovjekovo dostojanstvo i na vrijednost očuvanja političkog mira. ${ }^{27} \mathrm{Iz}$ tog je razloga uloga odgojitelja u funkciji životnoga učitelja prijeko potrebna za potpuno stasanje odgajanika u zrelu kršćansku osobu, a u ovom slučaju u razumna kršćanskog vladara.

\subsection{Vladarovo djelovanje u političkoj zajednici}

Odgajanik budući vladar treba usvojiti vrlinu domoljublja jer "kako bi volio zemlju kojom vlada, vladar mora prema njoj gajiti osjećaje kao što ih prema svojoj djedovini gaji dobar seljak, ili dobar muž prema svojoj obitelji, i prije svega se mora truditi da onome tko

\footnotetext{
$24 \quad$ Isto, 181.

25 Isto, 181-183.

26 Erazmo Roterdamski, Kršćanski vladar, 183.

27 Usp. Constance M. Furey, Erasmus, Contarini, and the ReligiousRepublic of Letters, Cambridge University Press, New York, 2006., 30.
} 
ga nasljeđuje preda zemlju bolju nego što ju je bio primio«. ${ }^{28}$ Ljubav prema domovini i svome rodu osnovna je vrlina po kojoj se vladar treba ravnati da bi naposljetku mogao što bolje skrbiti za svoju političku zajednicu. Erazmovo je obrazloženje jednostavno "onaj tko želi biti voljen, neka sam voli i neka svoje građane veže istim načinom kao što i Bog uz sebe veže sve ljude - naime, svojom dobrotom ". ${ }^{29}$ Upravo su kršćanske vrijednost, kao što su istina, pravednost i ljubav pokretačke vrijednosti za budućeg vladara. Potrebno je da mu se na vrijeme ukaže na sve štetnosti loših navika te duhovne prednosti vrlina. Naime "varaju se oni koji naklonost mnoštva stječu ulagivanjem, zabavama i sramotnim potkupljivanjem. Ovim se stvarima i stječe neka pučka zahvalnost, prije nego baš naklonost, ali ona niti je iskrena niti trajna. U međuvremenu raste strašna pohlepa naroda kojoj naposljetku, kada naraste unedogled, više ništa nije dovoljno. I onda se narod buni nije li udovoljeno svim njegovim željama". ${ }^{30}$ Prije svega je potrebno da odgoj za vladara bude označen poštovanjem prema svim pripadnicima političke zajednice.

Svakako je potrebno da se u vladara ne osjeća ravnodušnost prema političkim poslovima, a napose onim poslovima koji se odnose na napredak i brigu za opće dobro. U tom smislu Erazmo naglašava: "u privatnom životu neka se vladar ponaša tako da mu nitko ne može ništa progovoriti. A u javnosti dolikuje vladara vidjeti kako radi samo ono što služi na opću korist. Neka njegovo srce radije bude prepoznato po riječima nego po odjeći. Među pukom neka se šiti štogod izađe iz vladarovih usta. Zatim treba najveću brigu posvetiti tome da njegove riječi odišu mudrošću i pokazuju duh dostojan dobra vladara". ${ }^{31}$ Erazmo je veoma jasan kad je posrijedi pitanje ponašanja i držanja vladara te eksplicitno daje do znanja kako je potrebno da budući vladar bude produhovljena osoba koja ima smisla za potrebe drugih ljudi, a osobito za pripadnike političke zajednice nad kojom vlada.

\section{MORALNI HABITUS KRŠĆANSKOG VLADARA}

Erazmo se svojedobno ozbiljno zalagao za ancien régime, to jest zagovarao je postojeći utemeljeni politički poredak koji će vladara postaviti u fokus za sva politička pitanja. Ključna je Erazmova ideja kako odgajanika od malena treba formirati u prosvijećenog vladara, ne kao apsolutističkog monarha, već dobrohotnog vladara koji će moći prepoznati potrebe političke zajednice i time pridonijeti

\footnotetext{
28 Erazmo Roterdamski, Kršćanski vladar, 207.

29 Isto, 209.

30 Isto, 209.

31 Erazmo Roterdamski, Kršćanski vladar, 215.
} 
napretku i općem dobru jednako za sve pripadnike političke zajednice. U tom kontekstu "vladar treba koliko god je moguće izbjegavati svaku novotariju. Naime, ako se nešto i preokrene u dobro, ipak je sama novotarija pogubna. Nikada se državno uređenje, javni običaji i davno prihvaćeni zakoni ne mijenjaju bez nemira. Stoga, postoji li nešto što se može trpjeti, to ne treba mijenjati, već podnositi ili $\mathrm{u}$ pravi čas preokrenuti u neku veću korist. S druge strane, ako je nešto takvo da se ne može podnositi, onda treba ispraviti, ali umjesno i polagano". ${ }^{32}$ Nesklon prema političkim promjenama Erazmo zagovara odliku strpljenja u vođenju političkih poslova kako se politička zajednica ne bi destabilizirala i politički potkopavala.

Nadalje, Erazmo ističe kako "vladar treba biti oštrouman i predan tome da bude svima po dobru zaslužan, a taj cilj nije sadržan samo u davanju. Jedne će pomoći darežljivošću, druge će zadužiti uslugom, unesrećene će svojim ugledom osloboditi, a mnoge će razumno posavjetovati. I srce mu mora biti takvo da smatra propalim onaj dan u kojem nije nekoga pomogao svojim dobročinstvom". ${ }^{33}$ Vladara bi, prema Erazmu, trebala krasiti dobrostivost i velikodušnost kako bi u potpunosti imao odlike predana kršćanina koji brine za druge ljude. Upravo će takav vladar moći valjano vladati te donositi ispravne zakone. Naime, "najbolji zakoni pod najboljim vladarom čine grad ili kraljevstvo sretnim. Najsretnija je ona država u kojoj se svi pokoravaju vladaru, a sam se vladar pokorava zakonima, dok sami, pak, zakoni odgovaraju iskonskom uzoru pravde i časti i ne obaziru se na ništa drugo osim na poboljšanje općeg dobra $\cdot{ }^{34}$ Kako bi neka politička zajednica zadržala stabilnost, potrebno je imati i pravedne zakone, koji će omogućiti očuvanje političke zajednice. U tom je smislu presudno i vladarovo držanje jer "dobar, mudar i neiskvaren vladar nije ništa drugo nego oživotvorenje zakona. Stoga se treba truditi da izdaje najbolje i po državu najkorisnije zakone, a ne mnoštvo njih. Naime, dobro uređenoj državi, pod dobrim vladarom i poštenim činovnicima, dostaje vrlo malen broj zakona; u suprotnom slučaju, neće ih biti dovoljno koliki god im bio broj«. ${ }^{35}$ Dakle stabilnu političku zajednicu ne čini mnoštvo političkih zakona, već moralno i čestito djelovanje svih pripadnika političke zajednice, a prije svega samoga vladara jer je njegova primarna uloga da svojim besprijekornim držanjem potakne na ispravno ponašanje i ostale članove političke zajednice.

\footnotetext{
32 Isto, 217-219.

33 Isto, 231.

34 Erazmo Roterdamski, Kršćanski vladar, 235.

35 Isto, 235.
} 


\subsection{Važnost i uloga kršćanskih vrlina}

Velika je opasnost za političku zajednicu, prema Erazmu, besposlica, štoviše, dokolica, koja pojedince ne motivira na rad. Sukladno tome on ističe: "najveći dio nevolja svih država rađa se iz dokolice, koje se svi žele različitim sredstvima dokopati. Kada se jednom naviknu na nerad, a nestane sredstva za takav život, onda ljudi pribjegavaju opakim spletkama da bi to namirili. Stoga vladarova budnost mora biti usmjerena na to da među svojima ima što manje besposličara; neka ih ili natjera na rad ili istjera iz države". ${ }^{36}$ Erazmova je nakana da se mladog odgajanika, a posebice ako će postati vladar, pouči pravednosti i strogosti kako bi uklonio svaki oblik ponašanja u političkoj zajednici, koji bi je na koncu mogao destabilizirati.

Erazmo zagovara prisutnost socijalne dimenzije zakona jer će time štititi slabe i potlačene, odnosno: "Humanost zakona neka nadomjesti ono što im njihov položaj uskraćuje. Stoga treba oštrije kazniti zlodjelo prema siromahu nego uvredu bogataša, strože korumpiranog dužnosnika nego nepoštenog građanina, opakog plemića više nego podmuklog pučanina". ${ }^{37}$ Kako ne bi nastala tiranija, potrebno je imati u političkoj zajednici regulativne institucije koje će moći suzbijati bilo kakav mogući politički nered i upadanje u veću političku krizu. Svakako, tvrdi Erazmo, "dobar bi vladar najstrože trebao suditi one koji nevaljalo sprovode zakone, jer sam je vladar prvi među čuvarima zakona. Stoga je korisno da postoji što manji broj zakona, zatim da budu što pravedniji i što primjereniji općoj koristi, a osobito je bitno da narod bude što bolje s njima upoznat". ${ }^{38}$ Temeljni je Erazmov postulat za odgajanika, ukoliko mu okolnosti dozvole da postane vladar, briga za opće dobro, a tek nakon što osvijesti važnost i neophodnost benevolentnosti, takav vladar može vladati mudro, pravedno i u kršćanskoj ljubavi prema drugima.

\subsection{Ključne obveze vladara u Kršćanskom vladaru}

Nerijetko Erazmo u svom Kršćanskom vladaru veoma eksplicitno ističe kako je za političku zajednicu pogubna pokvarenost političkih dužnosnika. Štoviše "sramota je da postoje oni koji se zakonima služe kao nekom mrežom i rade samo na tome da njome uhvate što veći broj ljudi, ne vodeći brigu o državi, već se ponašaju kao da love plijen". ${ }^{39}$ Za manipulacije i zloupotrebe zakona Erazmo odluč-

\footnotetext{
$36 \quad$ Isto, 243.

37 Isto, 247.

38 Erazmo Roterdamski, Kršćanski vladar, 257-259.

$39 \quad$ Isto, 259.
} 
no kaže kako su takvi postupci krajnje nevaljali te moralno nedopustivi, a posebno za vladara koji je poučen u kršćanskim moralnim vrijednostima. Valja također istaknuti da je Erazmo i kao crkveni, ali i društveni reformator nastojao utjecati na pobuđivanje svijesti u političkoj zajednici. U tom smislu Džinić ističe da je Erazmo "kao plodove istinske reforme želio Crkvu čiji će članovi biti zreli i razboriti kršćani, htio je da pojedinci i pojedine zajednice dobiju snažnije mjesto u okviru Crkve i njezinih autoriteta, ali i da sve to skupa bude dosegnuto na polagan i miran način" " ${ }^{40}$

Erazmova je odgojna filozofija utemeljena u kršćanskoj filozofiji odgoja i posve je kristocentrična. Prema tome, potrebno je budućeg vladara odgojem poučiti o kršćanskoj etici ljubavi, kako bi mogao benevolentno vladati. Prijeko je potrebno budućeg vladara dovesti do toga kako "dobar vladar mora duboko u sebi biti uvjeren da ne može napraviti ništa veličanstvenije, nego da onu državu koju mu je sudbina dodijelila učini sjajnijom i u svim područjima uzornijom «. ${ }^{41}$ Ovdje valja istaknuti kako je konačna Erazmova nakana osvijestiti mladog odgajanika koji se priprema za vladara, da je političkoj zajednici za stabilnost prijeko potrebno imati vrlog i čestitog vladara, jer će tek tada takav vladar moći brinuti za opće dobro same političke zajednice. Ukratko, tvrdi Erazmo, "državu najbolje pomaže primjer dobra vladara, njegova mudrost i marljivost; zatim poštenje magistrata i činovnika, moralnost svećenika, izbor učitelja, pravedni zakoni i obrazovanje koje ljude usmjerava prema poštenju. (...) To je filozofija kršćanskog vladara, biti brižan i dosjetljiv kod takvih stvari. Doista je dostojno kršćanskih vladara u tom pravcu mudro djelovati i usmjeriti svoje odluke» ${ }^{42}$ Erazmova filozofija odgoja za kršćanskog vladara detaljno elaborirana u Kršćanskom vladaru, odgovara zašto odgajati te ozbiljno podsjeća na neophodnost i važnost kršćanskih vrijednosti koje su potrebne vladaru kako bi poučen u kršćanskoj etici ljubavi mogao vladati za summum bonum čitave političke zajednice.

\section{ZAKLUUČAK}

U ovome članku iznesene su osnovne misli o odgoju i kršćanskim vrlinama dobra vladara prema Erazmovu poimanju u djelu Kršćanski vladar. Erazmo problematici odgoja pristupa temeljito, napose imajući u vidu važnost vladarove uloge. Motiviran je kršćan-

40 Ivo Džinić, Reformacija i(li) revolucija: Erazmo Roterdamski i Martin Luther, Filozofska istraživanja, 38 (2018.) 4, 737-746, 743-744.

41 Erazmo Roterdamski, Kršćanski vladar, 285.

42 Erazmo Roterdamski, Kršćanski vladar, 287. 
skim idealom čestita odgojena čovjeka, koji ne robuje svojim strastima, već se odlikuje krepostima jer je bitan dio svoje moralne poduke zadobio od uzornoga kršćanskog odgojitelja. Temeljna je nakana Erazmova Kršćanskog vladara potaknuti odgojitelja da budućeg vladara odgoji i pouči o svim kršćanskim vrijednostima koje su mu neophodne za pravednu i dobru vladavinu. Budućeg vladara želi temeljito poučiti o svim vrijednostima koje kršćanstvo kao religija zagovara, jer će jedino kršćanski vladar moći biti dobar vladar koji brine za opće dobro političke zajednice. Kršćanski vladar Erazmovo je filozofsko djelo u kojem se zauzima za odgoj dobro podučena vladara u svim kršćanskim i teološkim vrlinama, te naposljetku čestita vladara koji će biti uzor drugima i u svoju vladarsku političku agendu najprije postaviti brigu za opće dobro čitave političke zajednice.

\section{ERASMUS' CHRISTIAN PHILOSOPHY OF EDUCATION AS A GROUNDED EDUCATION FOR THE SOVEREIGN}

\section{Summary}

In the article, the author problematizes and establishes the ultimate meaning of Erasmus' The Education of a Christian Prince, which Erasmus prepared as a manual on Christian education for the then young King Charles V of Habsburg. The article is divided into three parts or three chapters and a total of seven smaller chapters; five smaller chapters refer to the second unit, and two smaller chapters to the third unit. In short, the first part talks about the final ideal of Erasmus Christian sovereign, the second part talks about Erasmus Christian philosophy of education, and finally the third part talks about the necessary habitus of a Christian sovereign. By thoroughly elaborating Erasmus Education of a Christian Prince, on the basis of concrete and verified and argued reasons, the author finds in the article that Erasmus' reflection on education as a Christian philosophy of education, definitely focused on educating sovereigns in the Christian ethics of love and virtue, aimed at governing the common good of the political community.

Key words: philosophy of education, Erasmus of Rotterdam, Education of a Christian Prince, sovereign, virtue. 